\title{
Belief and credence: why the attitude-type matters
}

\section{Elizabeth Grace Jackson}

\section{Philosophical Studies}

An International Journal for Philosophy in the Analytic Tradition

\section{ISSN 0031-8116}

Volume 176

Number 9

Philos Stud (2019) 176:2477-2496

DOI 10.1007/s11098-018-1136-1

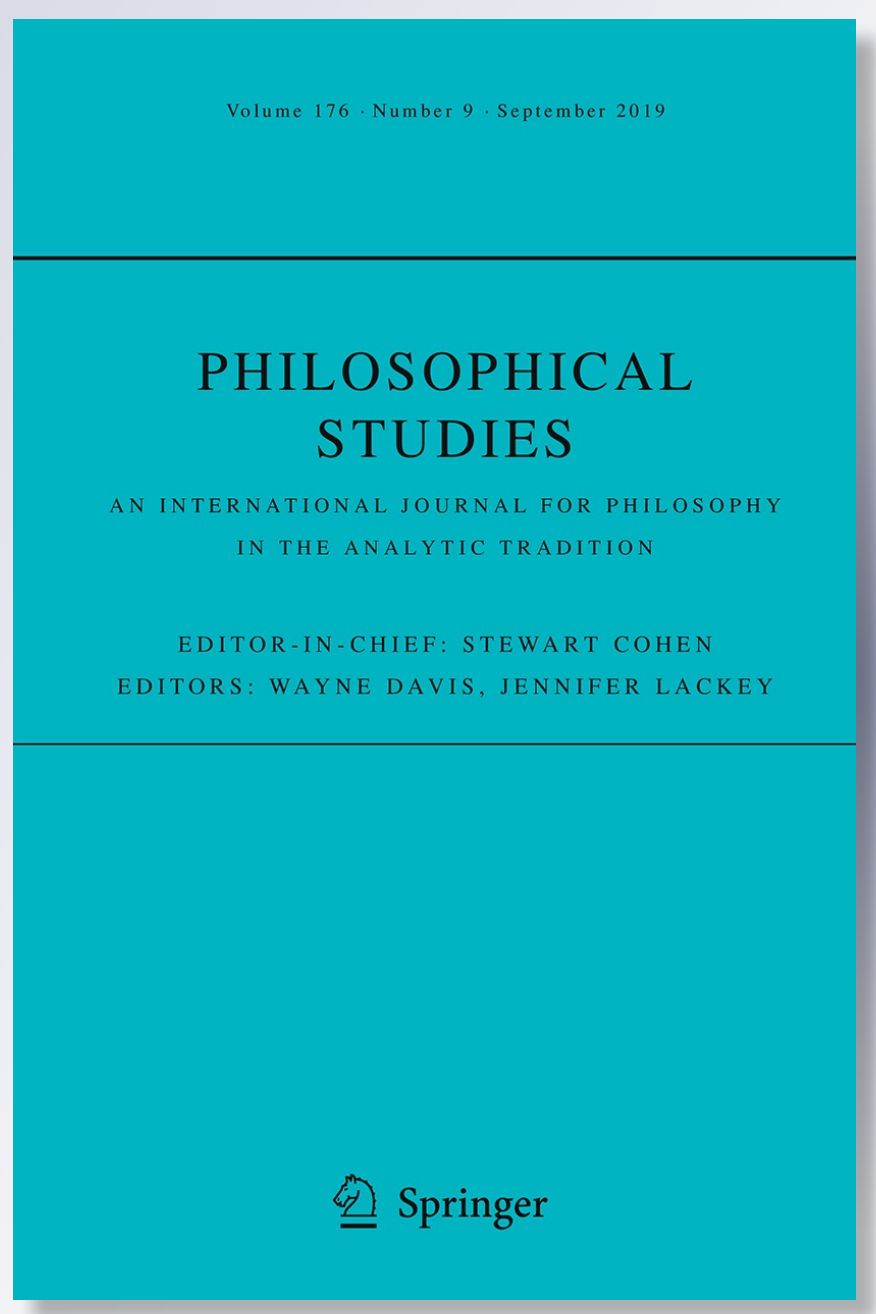

Springer 
Your article is protected by copyright and all rights are held exclusively by Springer Nature B.V.. This e-offprint is for personal use only and shall not be self-archived in electronic repositories. If you wish to self-archive your article, please use the accepted manuscript version for posting on your own website. You may further deposit the accepted manuscript version in any repository, provided it is only made publicly available $\mathbf{1 2}$ months after official publication or later and provided acknowledgement is given to the original source of publication and a link is inserted to the published article on Springer's website. The link must be accompanied by the following text: "The final publication is available at link.springer.com". 


\title{
Belief and credence: why the attitude-type matters
}

\author{
Elizabeth Grace Jackson ${ }^{1}$
}

\begin{abstract}
In this paper, I argue that the relationship between belief and credence is a central question in epistemology. This is because the belief-credence relationship has significant implications for a number of current epistemological issues. I focus on five controversies: permissivism, disagreement, pragmatic encroachment, doxastic voluntarism, and the relationship between doxastic attitudes and prudential rationality. I argue that each debate is constrained in particular ways, depending on whether the relevant attitude is belief or credence. This means that (i) epistemologists should pay attention to whether they are framing questions in terms of belief or in terms of credence and (ii) the success or failure of a reductionist project in the belief-credence realm has significant implications for epistemology generally.
\end{abstract}

Keywords Belief - Credence · Permissivism · Uniqueness · Disagreement · Pragmatic encroachment · Doxastic voluntarism · Prudential rationality

\section{Introduction}

Sometimes, we simply believe things. I believe my car is in the parking lot outside, that $1+1=2$, and that my coffee is getting cold. Belief is the attitude of taking some proposition to be the case or representing it as true. Belief is a categorical attitude in the sense that it is not degreed; either one believes a proposition or one does not. ${ }^{1}$ There

\footnotetext{
${ }^{1}$ For the purposes of this paper, I will be assuming or stipulating that belief is a categorical attitude. Of course, many epistemologists use the phrase "degrees of belief," which indicates that beliefs (or

Elizabeth Grace Jackson

Ejackso9@nd.edu

1 Department of Philosophy, University of Notre Dame, 100 Malloy Hall, Notre Dame, IN 46556, USA
} 
are three belief-like attitudes one can take toward a proposition $\mathrm{p}$; one can believe $\mathrm{p}$, one can withhold belief with respect to $\mathrm{p}$, and one can disbelieve $\mathrm{p}$ (which is usually assumed to be the same as believing not-p). For example, I withhold belief that there are an even number of hairs on my head, and I disbelieve that the Cavs won the 2018 NBA finals.

However, sometimes our attitudes are more complex than simple beliefs. While I am roughly $100 \%$ confident that $1+1=2$, I am closer to $99 \%$ confident my car is in the parking lot outside, and more like 50\% confident that a Republican candidate will win the next US election. I will follow many epistemologists in calling this second attitude credence. Credences are, in many ways, similar to the more everyday attitude of confidence, and roughly correlate with the subjective probability that some proposition is true. I will assume that, like beliefs, credences are propositional attitudes, ${ }^{2}$ but unlike beliefs, they come in degrees. Because they come in degrees, credences enable us to represent the world in a more fine-grained way; I believe that $1+1=2$ and that my coffee is cold, but I have a higher credence in the former than in the latter. Also unlike beliefs, credences (besides 0 and 1) don't treat the proposition in question as given, but leave the possibilities more open. A credence of 0.99 that it is raining leaves open the possibility that it is not raining in a way that a belief it is raining does not. ${ }^{3}$

Recently, three views about the relationship between belief and credence have emerged. The first is what one might call a credence-first view. On this view, credence is the fundamental attitude, and belief is a species of credence. On one version of this view, belief is the attitude of maximal credence, so belief is certainty that some proposition is true. ${ }^{4}$ On another credence-first view, belief is not maximal credence, but instead credence above some threshold, usually between 0.5 and 1.5

Footnote 1 continued

something like beliefs) come in degrees, but I will use the term "credence" here instead. For more on whether beliefs come in degrees, see Moon (2017).

2 While I am assuming that both beliefs and credences are propositional attitudes, this is controversial. For example, Moss (2018) holds that, rather than having propositional content, both beliefs and credences have probability spaces as content. I adopt the propositional content view as a simplifying assumption, but I do not think this is essential to my arguments.

${ }^{3}$ Generally, I will assume a standard, mainstream philosophy of mind conception of both beliefs and credences. On certain non-standard views of doxastic attitudes (e.g. the measure theory of mind [see Carr (forthcoming)], and interpretativism [see Dennett (1978, 1987, 1991) and Davidson (1984)] some of the points I make may not apply, or at least not apply in the ways I take them to apply. For example, given the measure theory of mind, the attitude-content distinction is measure-system relative. On this view, there's no psychological difference between e.g. having probabilistic beliefs and having credences. However, the distinction between probabilistic beliefs and credences is important for the points I make in this paper, so some of my arguments may rule out non-standard views of doxastic attitudes.

${ }^{4}$ For defenses and discussions of a credence-first view on which belief is maximal credence, see Levi (1991), Roorda (1995), Wedgwood (2012), Clarke (2013), Greco (2015) and Dodd (2016). Note that it is controversial on this view whether the attitude of certainty ought to be identified as credence 1 .

5 For defenses and discussions of a credence-first view on which belief is less-than-maximal credence, see Foley (1992, 1993, 2009), Hunter (1996), Bovens and Hawthorne (1999), Christensen (2004), Weatherson (2005), Douven and Williamson (2006), Ganson (2008), Sturgeon (2008), Frankish (2009), Chandler (2010), Smith (2010), Locke (2013), Dallmann (2014), Pettigrew (2015a, b), Leitgeb (2013, 2014), Dorst (2017) and Lee (2017a, b). 
Either way, on this view, believing is ultimately a matter of having a particular kind of credence.

A second view of the relationship between belief and credence is the belief-first view. ${ }^{6}$ On this view, belief is the fundamental attitude and credence is a species of belief. The fine-grained/numerical features of credence are built into the content of what is believed. On one version of this view, credences are beliefs with probabilistic content. A 0.99 credence it is raining is actually just the belief the probability it is raining is 0.99 ; a 0.5 credence the coin will land heads is a belief with the content the probability the coin will land heads is 0.5 . However, it is worth noting that the content need not be about probabilities per se; it could instead involve epistemic modals or some other kind of numerical structure. What is central to the belief-first view, however, is that the numerical structure is part of the content rather than part of the attitude, and the relevant attitude is simply belief. ${ }^{7}$

A third view is what some have called pluralism or dualism; on this view, both belief and credence are equally fundamental. We have both attitudes and neither is reducible to the other. This view is more complex, but proponents of dualism maintain it can nonetheless better explain our epistemological concepts and mental lives. On some versions of dualism, belief and credence are two different epistemic tools that we use for different purposes. The dualist view has recently been growing in popularity, and there have been both philosophical and psychological arguments proposed for dualism. ${ }^{8}$

The thesis of this paper is that the relationship between belief and credence is a central issue for epistemology. Specifically, I will consider each of the above views: belief-first, credence-first, and dualism, and argue that each view has significant implications for other debates in epistemology. ${ }^{9}$ If I am right, then whether a reduction in the belief-credence realm is successful is a significant and pivotal question in epistemology. Further, epistemologists ought not slide between attitudes, and should be careful making an argument considering only one attitude and then taking their argument to generalize. For example, an argument for permissivism about credence may not entail permissivism about belief; one ought not assume one has established permissivism is true if one has only argued for permissivism about credence.

I will focus on five debates: whether evidence can be permissive (Sect. 2), how we ought to respond to disagreement (Sect. 3), whether our practical interests can affect the epistemic rationality of doxastic attitudes (Sect. 4), whether we have control over our doxastic attitudes (Sect. 5), and the relationship between prudential

\footnotetext{
${ }^{6}$ For defenses and discussions of belief-first, see Harman (1986, 2008), Lance (1995), Holton (2008, 2014) Plantinga (1993: Chapter 1), Easwaran (2015), Moon (2018, forthcoming) and Jackson and Moon (MS).

7 Although this may not be sufficient for a belief-first view. For example, Moss (2018) argues for a simple-attitude, complex-content account of both beliefs and credences, but her view is not a belief-first view. See Footnote 2.

${ }^{8}$ For defenses and discussions of dualism, see Pollock (1983, 1994), Adler (2002: 9.1), Frankish (2004), Hawthorne (2009), Sosa (2011: Chapter 4), Weisberg (2013, forthcoming), Friedman (2013a), Ross and Schroeder (2014), Buchak (2014), Littlejohn (2015), Pettigrew (2015b), Carter et al. (2016) and Staffel (2017, 2018, forthcoming).

9 See Hajek and Lin (2017) for an important complementary paper. They examine points of connection and disconnection between formal and traditional epistemology and consider some of the same debates I consider, such as pragmatic encroachment and the role of belief and credence in rational action.
} 
rationality and doxastic attitudes (Sect. 6). For each controversy, I will show that belief-first, credence-first, and dualism constrain the debate-sometimes, in radical ways. I conclude with some upshots and suggestions for further research (Sect. 7).

Two caveats before I begin. First, I am not arguing for a particular view of the relationship between belief and credence. Instead, I am exploring what each view would say about other debates in epistemology. This paper involves many conditional claims; I will leave it to the reader to draw her own conclusions. Second, these controversies are complex and multi-faceted, and most of them have a large and growing literature. There are many implications that I will not have space to cover in this paper. Nonetheless, I hope my discussion will at least suffice to show the centrality of the belief-credence question for each debate in epistemology. This paper will point to many places in which further research is needed.

\section{Permissivism}

\subsection{Permissivism and uniqueness}

The permissivism debate is about whether there is ever any slack between a body of evidence and what it is epistemically rational to conclude, given that evidence. Permissivism is the view that, sometimes, for a proposition and a body of evidence, there is more than one rational doxastic attitude. ${ }^{10}$ For example, a permissivist might hold that two people could have all the same evidence about whether God exists-e.g. they both know about the cosmological and ontological arguments and are both aware of the problem of evil and the problem of divine hiddenness. Nonetheless, it is at least possibly true that, e.g. one rationally believes God exists and the other is rationally agnostic. Or one might have a higher credence than the other without compromising rationality. ${ }^{11}$ Thus, a permissivist maintains that one's body of evidence does not always rationally oblige one to hold a certain doxastic attitude toward a proposition.

Defenders of uniqueness deny this: uniqueness is the view that, for every body of evidence and proposition, there is always a single rational doxastic attitude. ${ }^{12}$ In response to the above example regarding belief in God, a proponent of uniqueness might insist that the agents in question do not actually share evidence; there must be a difference in evidence to justify a difference in attitudes. If the permissivist insists that they do share evidence, then the advocate of uniqueness will conclude that one of them is irrational.

\footnotetext{
${ }^{10}$ Main defenders of permissivism include Ballantyne and Coffman (2011), Kelly (2013), Meacham (2014) and Schoenfield (2014, 2018).

11 In the context of the belief/credence relationship, a more precise way to state the permissivist thesis would be that, given a body of evidence, there is more than one rational doxastic attitude of a particular type. This modification is needed because the view that a body of evidence permits a particular credence and a particular belief-attitude at the same time is not sufficient to count as permissivism. For example, my evidence might uniquely determine that I ought to have both a 0.9 credence in $\mathrm{p}$ and believe $\mathrm{p}$; this does not entail permissivism. Thanks to Geoffrey Hall.

12 Main defenders of uniqueness include White (2005, 2013), Feldman (2007), Hedden (2015), Greco and Hedden (2016) and Dogramaci and Horowitz (2016).
} 


\subsection{Implications of the belief/credence relationship}

Implicit in the above discussion is a distinction between two types of permissivism:

Credal permissivism Possibly, a body of evidence permits more than one rational credal-attitude.

Belief permissivism Possibly, a body of evidence permits more than one rational belief-attitude.

To see how these come apart, note that one could consistently maintain credal permissivism but deny belief permissivism. It might be that sometimes, a body of evidence permits more than one credence, but always requires one of the three belief-attitudes (belief that $\mathrm{p}$, withholding belief, or belief that not-p). ${ }^{13}$ The evidence could allow one to believe $p$ and have a credence of 0.8 or to believe $p$ and have a credence of 0.9 , but not allow for withholding belief or belief that not-p.

Before discussing how views on the relationship between belief and credence constrain the permissivism debate, it is worth noting that on the traditional finegrained credence model, credal uniqueness seems implausible. If credal uniqueness is true, then there is a single, fine-grained rational credence for a body of evidence. But it seems overly demanding to insist that I am irrational if I don't adopt a credence of, e.g. 0.675 , given my evidence. ${ }^{14}$ Thus, at least at first blush, credal permissivism seems more plausible that credal uniqueness.

Let's then suppose credal permissivism is true, and further suppose that a credencefirst view of the relationship between belief and credence is true. On this view, one's evidence would sometimes permit a range of rational credences, and belief would be a matter of having a credence above a particular threshold. This seems to lend itself to belief permissivism, as there seems to be no principled reason to think that the range of permitted credences could not straddle the threshold for belief. Thus, it seems natural to think that the conjunction of credence-first and credal permissivism (which is independently plausible) entails belief permissivism. ${ }^{15}$

Belief-first and dualism do not as obviously lend themselves to belief permissivism, so some who are attracted to uniqueness may want to adopt one of these views of the belief-credence relationship instead. Further, uniqueness about belief does not seem as prima facie implausible as uniqueness about credence, so whether belief permissivism is true seems like a more substantive question than whether credal permissivism is true. ${ }^{16}$ Thus, the belief-first and dualist views might provide a more interesting model on which to debate permissivism; e.g. could

\footnotetext{
${ }^{13}$ One might also deny credal permissivism but maintain belief permissivism. For example, one might be a pragmatist about rational belief, so rational belief is a matter of both stakes and evidence, but be a purist and uniquer about credences, such that rational credence mirrors, and is solely determined by, one's evidence. Thanks to Michael Hatcher.

${ }^{14}$ See Kelly (2013), Douven (2009), Schoenfield (2014) and Decker (2012).

15 Thanks to Michael Hatcher.

${ }^{16}$ As Kelly (2013) points out, an alternative route for defenders of uniqueness is to appeal to fuzzy or interval credences. I discuss other kinds of mental states besides belief and precise credences briefly in the conclusion (Sect. 7).
} 
rationality and a body of evidence ever permit both believing $\mathrm{p}$ and withholding with respect to $\mathrm{p}$ ?

Further, on a dualist picture, credal permissivism and belief permissivism can potentially come apart quite a bit. Of course, this will partially depend on whether there are normative connections between belief and credence (for example, whether the Lockean thesis is true, and rational belief that $\mathrm{p}$ requires a rational credence in $\mathrm{p}$ above some threshold). However, dualism is merely a descriptive, rather than a normative thesis, and this allows for multiple combinations of views about permissivism (permissivism about one attitude, uniqueness about the other, permissivism about both, uniqueness about both, etc.).

\section{Disagreement}

\subsection{Steadfastness and conciliationism}

How should we respond to disagreement? Should we alter our opinion in some way? Or is it fine to maintain our previously held opinion? The disagreement debate concerns these questions. Central to this debate is the concept of an epistemic peer-roughly, someone who is your epistemic equal. (For example, according to Kelly, epistemic peers have approximately the same evidence and the same epistemic virtues). ${ }^{17}$

There are two primary positions in the disagreement debate. Conciliationists maintain that the mere fact that an epistemic peer disagrees with you is a reason to alter your doxastic attitudes in some way. For example, suppose you and your friend, who is equally good at math as you (i.e. your epistemic peer) are at a restaurant, trying to figure out how to split the bill. You both calculate separately, and you determine that the cost is $\$ 22$ a person, while they calculate that it is $\$ 26$ a person. Intuitively, you should not dogmatically believe you are right and they are wrong; you should withhold belief and/or lower your credence in your previously held opinion, as you have no reason to think that you are more reliable than your friend. ${ }^{18}$

The other position in this debate is steadfastness, or the view that the mere fact a peer disagrees with you is not always a reason to alter your doxastic attitudes in some way. Steadfasters may think that, in some cases, peer disagreement should cause us to alter our attitudes, e.g. because disagreement functions as higher-order evidence against a previously held opinion. ${ }^{19}$ However, steadfasters think it is at least sometimes, if not often, appropriate instead to remain true to your previous opinion, even in the face of peer disagreement. For example, we encounter peers daily who disagree with us on political and religious matters, but it doesn't seem irrational to nonetheless maintain our political and religious convictions, even with high confidence.

\footnotetext{
17 Kelly (2005). There are different, incompatible notions of peerhood in the disagreement literature; another notion of peerhood that centers around reliability is found in Elga (2007: 487). I mention Kelly's definition to give the reader a general understanding of what being an epistemic peer amounts to, but nothing in my argument turns on adopting a particular view of peerhood.

18 See Christensen (2007, 2009, 2016).

19 Kelly (2005).
} 


\subsection{Implications of the belief/credence relationship}

Suppose that a belief-first view is true, and beliefs are the fundamental attitude. Suppose also that conciliationism is true, and that we should change our doxastic attitudes in the face of peer disagreement. The combination of these two views actually leads to some puzzles. The coarse-grained nature of a belief-first view makes it difficult to see what conciliating would look like. Recall that there are only three belief-like attitudes one can take toward a proposition. If I believe $\mathrm{p}$ and you, my peer, believe not-p, then it seems like we should both withhold belief. But what if I believe $\mathrm{p}$ and you withhold? Or if I withhold and you believe not-p? If conciliationism is a matter of altering one's attitudes, it is unclear what this change ought to look like-there is no intermediary attitude.

One potential way to solve this puzzle is to suggest that conciliating in cases like these should involve changing the content that is believed, rather than changing one's attitude toward a particular proposition. For example, if I believe $\mathrm{p}$ and you withhold, maybe I should neither believe p nor withhold, but instead form a new belief with the content "probably p." This suggestion is both interesting and puzzling. It is interesting because conciliationism ends up amounting to "trading" one belief for another, rather than altering one's attitude toward a particular content. At the same time, it raises a number of questions, most notably, what attitude should one take toward the original proposition $\mathrm{p}$ ? It seems inappropriate for me to believe $\mathrm{p}$ or withhold, and I definitely shouldn't believe not-p. Is there an additional perspective, having-no-attitude-at-all toward $\mathrm{p}$, where $\mathrm{p}$ is a proposition you have considered? Maybe, but talk of such an attitude is rare, if not virtually absent, from the literature ${ }^{20}$; further, it is unclear that this is the appropriate attitude for me to take toward $\mathrm{p}$ in this situation. There is room for further work on how one would combine a belief-first view with conciliationism.

Suppose instead that credence-first is true. Prima facie, it might seem as though a credence-first view lends itself nicely to conciliationism, because whenever you encounter a peer who disagrees with you, you can simply average your credence with theirs and "split the difference" with them. However, on closer examination, a credence-first conciliationist view may not be so straightforward. Consider a case for Christensen.

I am a doctor determining what dosage of a drug to give my patient. I'm initially inclined to be very confident in my conclusion, but knowing my own fallibility in calculation, I pull back a bit, say, to 0.97 . I also decide to ask my equally qualified colleague for an independent opinion. I do so in the Conciliatory spirit of using her reasoning as a check on my own. Now suppose I find out that she has arrived - presumably in a way that also takes into account her fallibility - at 0.96 credence in the same dosage. ${ }^{21}$

\footnotetext{
${ }^{20}$ One exception is Friedman (2013b: 170).

${ }^{21}$ Christensen (2009: 759).
} 
In this case, you are technically encountering peer disagreement, as your colleague is less confident in the proposition than you. According to the split the difference view, you should be slightly less confident that you should give that dosage to your patient (i.e. alter your credence to 0.965 ). However, Christensen concludes that "it seems that the rational thing to do is for me to increase my confidence that this is the correct dosage, not decrease it as difference-splitting would require." ${ }^{22}$ Even though she is less confident than you are, she is confident enough that it confirms, rather than calls into question, your conclusion about the dosage.

Of course, not all will share Christensen's intuitions about this case, but I do think there are more general lessons to be learned. First, as Christensen notes, "mechanical difference splitting with peers" in a credence framework might not straightforwardly apply in every case. ${ }^{23}$ Second, the fine-grained nature of credences may, in some cases, make it seem like there is disagreement when the situation is better described as one of agreement. Consider another example: suppose I hold an unpopular view in philosophy with a credence of 0.95 , and I am discouraged because everyone I encounter seems to reject my view. Then, I meet someone else with a 0.90 credence in that view. I will likely experience comfort and happiness to find someone who shares my inclinations, and I would probably even describe them as someone who agrees with me. It seems unlikely that I would spend a lot of time focusing on the fact that I am slightly more confident than they are. Thus, when the attitudes in question are extremely fine-grained, agreement and disagreement start to blur together, and the proper way to conciliate with epistemic peers may not be straightforward.

Finally, suppose that dualism is true. Then, it seems as though conciliationism and steadfastness can be combined in interesting ways. For example, one might be a steadfaster about belief but a conciliationist about credence. ${ }^{24}$ Further, if one thinks there is a normative relationship between the attitudes, it might be that conciliationism is fundamentally true of one attitude, but derivatively true of another; e.g. the only reason one ought to alter one's beliefs in response to disagreement is in virtue of the fact that one ought to alter one's credences, as it is irrational to alter one's credences drastically without a change in one's beliefs. ${ }^{25}$

\section{Pragmatic encroachment}

\subsection{Pragmatism and purism}

The pragmatic encroachment debate is about whether practical interests can affect the epistemic rationality of particular kinds of mental states. ${ }^{26}$ Early in the debate, most people were focusing on whether practical factors can affect

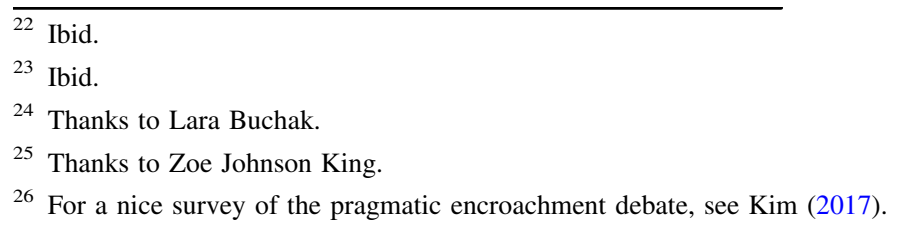


knowledge ${ }^{27}$ but lately, many have been focusing on whether the practical can affect epistemic justification. ${ }^{28}$ (Of course, the practical might affect knowledge by affecting epistemic justification, so these foci are not mutually exclusive and are even potentially complementary). Since this paper concerns beliefs and credences, I will focus on the ways that the practical might affect epistemic justification or epistemic rationality, as justification/rationality apply more straightforwardly to beliefs and credences than does knowledge. ${ }^{29}$

Pragmatists argue that epistemic justification depends, at least in part, on the practical. Purists deny this and maintain that epistemic justification is not affected by our practical interests. One traditional example to motivate pragmatism is as follows. Suppose that Hannah is driving home on a Friday afternoon, and plans to stop by the bank to deposit a check. There is no urgency to deposit this check, and Hannah drives by the bank and notices the lines are extremely long. She remembers that she was at the bank a few weeks ago on a Saturday, and thus justifiedly believes/has a high credence that the bank is open tomorrow.

In the second version of the case, Hannah is also driving home on a Friday afternoon and plans to stop by to deposit a check at the bank. She also sees very long lines when she drives by the bank. However, she has very little money in her account and her mortgage payment is due Monday. If she doesn't get the check deposited by that weekend, she will default on her mortgage and go bankrupt. She has the memory of being at the bank a few weeks ago on a Saturday, but she also knows her memory is fallible and banks do change their hours. It seems like Hannah does not have justification to believe/have a high credence that the bank is open, even though the epistemic aspects of the case remain the same. Thus, at least in some cases, it seems like stakes alone can affect the rationality of our doxastic attitudes. $^{30}$

Purists resist this verdict and offer an alternative explanation for our differing intuitions. For example, our intuitions might not clearly distinguish epistemic justification to believe/have a high credence that the bank is open tomorrow, and practical justification to act as if the bank is open tomorrow. There is also a correlation between stakes and how much evidence it seems one ought to gather before taking action, so our intuitions might be the result of a confusion between epistemic justification and duties to gather evidence before acting. ${ }^{31}$

\footnotetext{
27 See Hawthorne (2003), Stanley (2005) and Fantl and McGrath (2002, 2010).

28 See Schroeder (2012) and Ross and Schroeder (2014). Further, Fantl and McGrath (2002, 2010) also talk quite a bit about pragmatic encroachment on epistemic justification.

29 One reason for this is because it is controversial whether credences can be knowledge or knowledgelike. For an argument that credences can amount to knowledge, see Moss $(2013,2018)$.

30 These cases are adopted from Stanley (2005: 3-4).

31 See Nagel (2008, 2010a).
} 


\subsection{Implications of the Belief/Credence Relationship}

There are two ways one might be a pragmatist:

Credal pragmatism The justification/rationality of a credence depends, at least in part, on practical interests. ${ }^{32}$

Belief pragmatism The justification/rationality of a belief depends, at least in part, on practical interests.

There are also two ways to be a purist: credal purism (the denial of credal pragmatism) and belief purism (the denial of belief pragmatism). Our judgments about these theses will depend on the relationship between belief and credence.

Suppose credence-first is true, and beliefs are a type of credence. It might seem that purism about credence would entail purism about belief-if rational credence isn't affected by the practical, and belief is just a matter of having a certain credence, then it would seem that rational beliefs aren't affected by the practical, either. However, recall that on a credence-first view, belief is a function of both one's credence and also a threshold required to count as believing. Thus, certain credence-first views can actually maintain both credal purism and belief pragmatism, if practical factors can affect the threshold for belief. ${ }^{33}$ For example, in a low stakes scenario, one might only need a 0.7 credence for rational belief, but if the stakes go up, one might need a 0.9 credence for rational belief. If, on the other hand, the threshold for belief does not vary with stakes, this would make space for a credence-first view that is purist about both belief and credence.

A belief-first view does not seem to be as flexible. Given belief-first, pragmatism about belief seems to lend itself to pragmatism about credence (and vice versa), and purism about belief seems to lend itself to purism about credence (and vice versa). Recall that according to belief-first, credences are just a matter of having beliefs with a particular content. It would be very odd if pragmatism were true about beliefs with certain contents but not other contents; it seems like pragmatism and purism ought to apply equally to both beliefs and credences, given belief-first.

Finally, suppose dualism is true. Dualism seems to allow for multiple combinations of belief pragmatism, credal pragmatism, belief purism, and credal purism. What combinations of views one can maintain will, again, depend on whether there are normative connections between belief and credence.

It is also worth noting that dualism can potentially offer a unique purist explanation for pragmatist intuitions. Recall that on the dualist view, we have both beliefs and credences, and many dualists maintain that beliefs and credences are two epistemic tools used for different purposes. ${ }^{34}$ There is additional psychological evidence that beliefs are useful in low-stakes scenarios, when we can assume certain

\footnotetext{
32 Some authors who mention or discuss this view include Stanley (2005: 88-89), Armendt (2007), Kim (2017: 7), Hajek and Lin (2017: 226), Moss (forthcoming) and Sturgeon (forthcoming).

33 Defenders of this view include Weatherson (2005), Ganson (2008), Fantl and McGrath (2010) and Pace (2011). For objections to this view, see Ross and Schroeder (2014).

${ }^{34}$ See Staffel (2017) and Weisberg (forthcoming).
} 
propositions in our reasoning but still reason accurately enough for our aims. For instance: it may be completely appropriate for me to believe my office mate, Rachel, is in the philosophy building because I saw her coat and backpack in the office, and rely on this belief if a friend casually asks me if Rachel is in today. On the other hand, credences are useful in high stakes cases, where precision and accuracy in reasoning are especially important. Returning to our example, if police are investigating a murder in the philosophy department and require a detailed list of everyone in the building that day, I ought to consider the possibility that Rachel was not actually in that day, since I never actually saw her, only her coat and backpack. ${ }^{35}$ Instead of believing and taking for granted that Rachel was in today, I should reason using my credence that she was in the building; this keeps the possibilities open and allows for a more accurate representation of my evidential situation. $^{36}$

Thus, it is open to the dualist to say that when the stakes rise, you shouldn't give up the relevant belief; you just shouldn't rely on it in reasoning. Instead, you should rely on your credence. Higher stakes call for more detailed, thoughtful reasoning, i.e. credence reasoning. But that you shouldn't use belief-reasoning doesn't entail you ought to give up the belief; rational belief doesn't depend on practical interests, but whether you should rely on a belief does. ${ }^{37}$

\section{Doxastic voluntarism}

\subsection{Voluntarism and involuntarism}

The doxastic voluntarism debate primarily concerns the question of whether we can ever have direct control over our doxastic attitudes. Direct control is the same kind of control we have over raising our hand; what precisely this kind of control amounts to is controversial. ${ }^{38}$ However, we can, via an agential act, raise our hand straightforwardly and directly; we can also choose not to raise our hand. Voluntarists maintain that, at least sometimes, we can control our doxastic attitudes in this way. Involuntarists deny that our doxastic attitudes can ever be controlled directly. ${ }^{39}$

\footnotetext{
35 This case is adapted from DeRose (2009).

36 See Webster and Kruglanski (1994, 1996), Nagel (2008, 2010a, b), Kahneman (2013) and Staffel (2017).

37 This argument is further developed in Jackson (MS).

38 As Hieronymi (2006: 48) points out, direct control and basic actions come apart.

39 Arguments for involuntarism include Williams (1970), Winters (1979), Alston (1988), Bennett (1990), Scott-Kakures (1994), Hieronymi (2006, 2009), Setiya (2008). Arguments for voluntarism include Radcliffe (1997), Ginet (2001), Shah (2002). See also Audi (2001), Feldman (2001), Ryan (2003) and Steup (2008).
} 


\subsection{Implications of the belief/credence relationship}

We can distinguish two ways voluntarism might be true:

Belief voluntarism Possibly, we have direct/voluntary control over our beliefs.

Credal voluntarism Possibly, we have direct/voluntary control over our credences.

How do various views on the belief-credence relationship affect what one might conclude about these types of voluntarism?

Suppose that credence-first is true. Then, the fundamental question in the doxastic voluntarism debate seems to be over whether credal voluntarism is true. However, the doxastic voluntarism literature has primarily concerned the attitude of belief, rather than the attitude of credence. ${ }^{40}$ While many philosophers seem unsympathetic to the idea that we could directly control our credences, few have discussed this in print or provided arguments for this conclusion. One exception is that some have suggested that we can't control our credences because credence simply tracks the amount of evidential support we have for a particular proposition. ${ }^{41}$ However, it is still a relatively unexplored question whether credal voluntarism is plausible.

But supposing credal voluntarism is implausible, what would a credence-first view say about belief voluntarism? While this may seem to imply that belief voluntarism is also implausible, there is at least one potential way to preserve belief voluntarism. If, somehow, we could control the threshold for belief, strict involuntarism could be true of credences, but we could control whether we believe by moving the threshold around. In some ways, this suggestion is similar to the one in Sect. 4.2 on which pragmatic factors can set the threshold for belief. The big question for this view seems to be whether it is plausible that we could directly control this threshold.

On a belief-first view, credal voluntarism and belief voluntarism seem to stand or fall together. If we can directly control some of our beliefs, it seems ad hoc to suggest we cannot directly control our beliefs with probabilistic content (at least it is unclear what would motivate this). Further, if we do not have direct control over our beliefs, then it seems like we would not have direct control over our probabilistic beliefs, either.

Dualism, by contrast, allows for more combinations of views. On a dualist picture, it seems like one could maintain belief voluntarism but deny credal voluntarism, or maintain credal voluntarism but deny belief voluntarism. And unlike the credence-first view, this wouldn't require the ability to directly control the threshold for belief. Thus, on a dualist picture, one could maintain strict credal involuntarism but nonetheless hold that sometimes, we can directly control whether or not we believe the proposition in question.

\footnotetext{
40 One exception to this is Pittard (MS).

41 Thanks to Lara Buchak.
} 


\section{Doxastic attitudes and rational action}

\subsection{Two models of rational action}

What makes an action rational? At least two different models have been developed in order to answer this question. The first is decision theory. On an orthodox decision theory model, an action is rational iff it maximizes expected value. ${ }^{42}$ The second is a belief-desire model; i.e. an action is rational iff it is appropriate given one's beliefs and desires. ${ }^{43}$ The main use for these models (at least in a philosophical context) is to give a normative theory of action-a theory that explains how one ought to act. ${ }^{44}$ For example, suppose it is rational for me to go to the library. On a decision theory picture, this is because my utility function is such that I value getting work done, and, given the ways the world might be, going to the library results in the best outcome, given my utility function. On a belief-desire picture, this action will be rational because I desire to get work done, I believe being at the library provides a quiet work environment, I believe in the past I've been productive when I've gone to the library, etc.

Note that both of these models involve an epistemic component and an axiological component. Decision theory takes probabilities (or credences) and utilities as inputs. The belief-desire model takes beliefs and desires as inputs. Both of these (and most other models of rational action as well) require some kind of input that represents the world or says something about what the world is like.

\subsection{Implications of the belief/credence relationship}

Given that rational action requires us to represent the world in a particular way, questions arise about the way beliefs and/or credences play a role in how we ought to act. How will one's commitments on the relationship between belief and credence affect one's views on the rationality of action? Do some views on belief and credence push us toward one model or another?

Suppose a credence-first view is true. Credence-first seems, at least prima facie, conducive to a decision theory model of rational action, as decision theory takes credences as inputs. One worry for this combination of views, however, is that there is psychological evidence we often fail (in serious and predictable ways) to maximize expected value. ${ }^{45}$ We fail at least partially because efficiency is often important in our decision-making processes, and when the stakes are quite low and/ or we have to make a decision quickly, it doesn't make sense to do an expected value calculation; this would require too much mental work. ${ }^{46} \mathrm{~A}$ decision-theorist

\footnotetext{
42 See Briggs (2014).

43 See Davidson (1963) and Bratman (1987).

44 Some (especially economists) additionally use them as descriptive theories, to explain action (rational or irrational), but using the models for this purpose is less common among philosophers.

45 See Kahneman and Tversky (1982).

46 See Weisberg (forthcoming).
} 
might respond that the fact that we fail to maximize expected value doesn't count against decision theory as a normative theory. Decision theory is a theory about ideal prudential rationality, not one that is meant to describe how we actually reason. This response makes sense, but there is still a worry in the neighborhood: is it plausible for agents like us to be guided by decision theory in all of our decision making? One might worry this an unrealistic prescription, given our cognitive limitations. In other words, one might worry that if decision theory is supposed to be an action-guiding norm for prudential rationality, using it for all decision making is too complex or requires too much mental effort. ${ }^{47}$

If one takes this sort of worry seriously, it might motivate the idea that a beliefdesire model of decision making is better suited to guide action for cognitively limited agents like us. A belief-desire model seems to fit nicely with the belief-first view, as it takes beliefs, rather than credences, as inputs. While this might guide action more realistically, given our cognitive limitations, the belief-desire model faces other worries. For example, there are cases where it is rational to act as if some proposition is true when one doesn't believe it or believes it is false. Suppose you are trying to decide whether allow your children to skate on a frozen lake. You believe the ice is solid, but you also realize there's a chance it is not. It might be rational to act as if the ice will crack and tell your children they cannot skate, even despite your belief the ice is solid. In a second case, suppose your brother has been missing for multiple months. There is a lot of evidence he is dead; so much evidence, in fact, you believe he is dead. However, you also know there's some chance you're wrong-there's a chance he's still alive, and for this reason, you don't give up hope, and you continue to search for him and try to get in contact with him. In both of these cases, you believe p, but acting as if not-p is rational for you, because (i) there is a non-zero chance that not-p and (ii) the stakes are sufficiently high. There are many other cases with a similar stricture; most cases of rational acceptance without belief will fit into this category. ${ }^{48}$ Probabilistic models of rational action, e.g. decision theory, seem more conducive to capturing the rationality of this kind of action.

A proponent of the belief-desire model/a belief-firster might respond by saying that cases like these are ones in which our probabilistic beliefs come into play. While you believe $\mathrm{p}$ in these cases, you also believe there is a non-zero chance that not-p, and you are acting on the basis of this second belief. ${ }^{49}$ This helps with the problem, but there is also the question of why you ought to act on the basis of your probabilistic belief there is a non-zero chance that not-p instead of your belief that p. Decision theory gives a nice answer to this question; it is clearly captured in the formal model. However, at least prima facie, on the belief-desire model, it is not clear why one ought to act on the probabilistic belief rather than the nonprobabilistic one.

\footnotetext{
47 Although a potential rejoinder here is that one's action is rational iff one can be represented as maximizing expected value. See Lewis (1974: 337).

48 See Cohen (2000).

49 For some work on how beliefs might guide action without credences, see Hawthorne and Stanley (2008), Lin (2013) and Easwaran (2015: 19).
} 
Finally, suppose dualism is true and we have both beliefs and credences and neither is fundamental. Some have worried that dualism is subject to the "Bayesian Challenge." ${ }^{50}$ The Bayesian Challenge is the worry that we do not need both beliefs and credences to explain the rationality of action (among other things). Credences alone seem to do quite well. If beliefs make the same prescriptions as credences, they seem superfluous; if they make different ones, we should trust those made by our credences (because, for example, it can be rational to act as if not-p even though we believe $\mathrm{p}$, as discussed above). Thus, beliefs are either unnecessary for decision making or guide us in the wrong direction. ${ }^{51}$

Several attempts to meet the Bayesian Challenge have been offered. Ross and Schroeder, for example, suggest that beliefs are the things that determine which possibilities one is considering in one's decision making. When $S$ believes $p, p$ is true in every state of the world in S's decision matrix. For agents like us, it is impossible to consider every possibility, so beliefs make reasoning manageable. ${ }^{52}$ Weisberg and Staffel suggest that we never reason with our belief in $\mathrm{p}$ and our credence in $\mathrm{p}$ at the same time, so when beliefs (rationally) play a role in our reasoning, it is because (for various reasons) we ought to rely on our belief rather than our credence. ${ }^{53}$ Along similar lines, Moon has suggested that it is possible for agents to have a belief that $\mathrm{p}$ without a credence that $\mathrm{p} .{ }^{54}$ If Moon is right, it seems as though agents who believe $\mathrm{p}$ without a credence must utilize their belief that $\mathrm{p}$ in order to reason about $\mathrm{p}$ and act on $\mathrm{p}$. Whether these various attempts to meet the Bayesian Challenge are successful is a judgment I will leave to the reader, but at minimum, it is not obvious that the Bayesian Challenge is devastating for dualism.

\section{Conclusion}

I conclude with some areas of further research. First, I have only considered the relationship between two kinds of attitudes: categorical beliefs and precise credences. However, epistemologists have recently suggested there might be other kinds of attitudes as well: imprecise/fuzzy/interval credences, ${ }^{55}$ attitudes of comparative confidence, ${ }^{56}$ etc. Including these attitudes in the debates could open up even more possibilities. For example, if uniqueness and credence-first are in tension, one might include fuzzy or interval credences in the domain of possible attitudes, and maintain that the evidence determines a unique fuzzy credence (even if it doesn't determine a unique precise credence). ${ }^{57}$ I have avoided talking about

\footnotetext{
50 See Kaplan (1996), Stalnaker (1984), Sturgeon (2008) and Frankish (2009).

51 See Weisberg (forthcoming).

52 Ross and Schroeder (2014), Tang (2015) and Staffel (2018).

53 Staffel (2017) and Weisberg (forthcoming).

54 Moon (forthcoming).

55 See Rothschild (2012), Schoenfield (2012, 2015) and Konek (forthcoming).

56 See Carter et al. (2016).

57 See Kelly (2013).
} 
this kind of move for the sake of space, but this is one potential way to expand my project. Also, if something about a particular debate in epistemology pushes us to adopt a more coarse-grained attitude, there is a question of when we should move to categorical belief, and when it might be better to instead move to an interval/fuzzy credence. More research could be done on this question.

A second view I have not considered is eliminativism. On both belief-first and credence-first, one attitude is reduced to the other, but on both views, the reduced attitude still exists. However, one might maintain, for example, that our concept of belief is a leftover from folk psychology, and there is no reason to hold that beliefs are psychologically real. Belief is not high credence or certainty; beliefs just do not exist. ${ }^{58}$ One could maintain a similar view of credence (although I am not aware of anyone who has argued for eliminativism about credence). ${ }^{59}$ Eliminativism about belief or credence might have different implications for these debates than reductionism; this is another area where further research is needed.

I conclude that the relationship between belief and credence is a significant one for epistemology, and one to which epistemologists should pay closer attention. It is also worth noting that answering questions about the relationship between belief and credence involves much philosophy of mind; in fact, it may be primarily a philosophy of mind question. Further, exploring the belief-credence relationship might also require diving into psychology and looking at what view of belief and credence is best supported by the empirical evidence. ${ }^{60}$ Thus, insofar as the relationship between belief and credence is a philosophy of mind/empirical question, epistemologists ought to be branching out into other fields. ${ }^{61}$

\section{References}

Adler, J. (2002). Belief's own ethics. Cambridge: MIT Press.

Alston, W. (1988). The deontological conception of epistemic justification. Philosophical Perspectives, 2, 257-299.

Armendt, B. (2007). Stake-invariant belief. Acta Analytica, 23(1), 29-43.

Audi, R. (2001). Doxastic voluntarism and the ethics of belief. In M. Steup (Ed.), Knowledge, truth, and duty: Essays on epistemic justification, responsibility, and virtue. Oxford: Oxford University Press.

Ballantyne, N., \& Coffman, E. J. (2011). Uniqueness, evidence, and rationality. Philosophers' Imprint, $11,1-13$.

\footnotetext{
58 See Jeffrey (1970), Churchland (1981), Maher (1993: pp. 152-155) and Pettigrew (2016).

59 Views that could be construed as credence-eliminativism include Holton (2008, 2014), and Horgan (2017). Whether these count as credence-eliminativism depend on how broad one's notion of credence is. For example, Holton denies that we have precise, point-valued credences, but maintains we have something called "partial beliefs" that stands in contrast to full beliefs.

${ }^{60}$ Weisberg (forthcoming) provides a notable example of how one might apply psychology to the beliefcredence question.

61 Thanks to Michael Hatcher, Ting Cho Lau, Greta Turnbull, Tobias Flattery, Lizzie Fricker, Julia Staffel, Fritz Warfield, Andrew Moon, Lara Buchak, Robert Audi, Daniel Nolan, Blake Roeber, Jeff Brower, and audiences at the 2017 Pavia New Trends in Epistemology Workshop, the 2017 Indiana Philosophical Association, and the 2017-2018 Notre Dame Dissertation Seminar for helpful comments and feedback that improved this paper in many ways.
} 
Bennett, J. (1990). Why is belief involuntary? Analysis, 50(2), 87-107.

Bovens, L., \& Hawthorne, J. (1999). The preface, the lottery, and the logic of belief. Mind, 108, 241-264. Bratman, M. (1987). Intentions, plans, and practical reason. Cambridge: Harvard University Press.

Briggs, R. (2014). Normative theories of rational choice: Expected utility. In E. N. Zalta (Ed.) The Stanford encyclopedia of philosophy. https://plato.stanford.edu/archives/spr2017/entries/rationalitynormative-utility/.

Buchak, L. (2014). Belief, credence, and norms. Philosophical Studies, 169(2), 285-311.

Carr, J. (forthcoming). Subjective probability and the content/attitude distinction. Oxford Studies in Epistemology.

Carter, J., Jarvis, B., \& Rubin, K. (2016). Belief without credence. Synthese, 193, 2323-2351.

Chandler, J. (2010). The lottery paradox generalized? British Journal for the Philosophy of Science, 61, 667-679.

Christensen, D. (2004). Putting logic in its place. Oxford: Oxford University Press.

Christensen, D. (2007). Epistemology of disagreement: The good news. Philosophical Review, 116(2), 187-217.

Christensen, D. (2009). Disagreement as evidence. Philosophy Compass, 4(5), 756-767.

Christensen, D. (2016). Conciliation, uniqueness and rational toxicity. Nô̂s, 50(3), 584-603.

Churchland, P. M. (1981). Eliminative materialism and the propositional attitudes. Journal of Philosophy, 78, 67-90.

Clarke, R. (2013). Belief is credence one (in context). Philosopher's Imprint, 13, 1-18.

Cohen, J. (2000). Why acceptance that p does not entail belief that p. In P. Engel (Ed.), Believing and accepting. Dordrecht: Kluwer.

Dallmann, J. (2014). A normatively adequate credal reductivism. Synthese, 191(10), 2301-2313.

Davidson, D. (1963). Actions, reasons, and causes. Journal of Philosophy, 60(23), 685-700.

Davidson, D. (1984). Inquiries into truth and interpretation. Oxford: Clarendon.

Decker, J. (2012). Disagreement, evidence, and agnosticism. Synthese, 187, 753-783.

Dennett, D. (1978). Brainstorms. Cambridge, MA: MIT Press.

Dennett, D. (1987). The intentional stance. Cambridge, MA: MIT Press.

Dennett, D. (1991). Real patterns. Journal of Philosophy, 87, 27-51.

DeRose, K. (2009). The case for contextualism. Oxford: Oxford University Press.

Dodd, D. (2016). Belief and certainty. Synthese, 194(11), 4597-4621.

Dogramaci, S., \& Horowitz, S. (2016). An argument for uniqueness about evidential support. Philosophical Issues, 26, 130-147.

Dorst, K. (2017). Lockeans maximize expected accuracy. Mind. https://doi.org/10.1093/mind/fzx028.

Douven, I. (2009). Uniqueness revisited. American Philosophical Quarterly, 46, 347-361.

Douven, I., \& Williamson, T. (2006). Generalizing the lottery paradox. British Journal for the Philosophy of Science, 57, 4.

Easwaran, K. (2015). How I learned to stop worrying and love Bayesian probabilities. Nous, 50(4), 1-38.

Elga, A. (2007). Reflection and disagreement. Nous, 41(3), 478-502.

Fantl, J., \& McGrath, M. (2002). Evidence, pragmatics, and justification. The Philosophical Review, 111, 1.

Fantl, J., \& McGrath, M. (2010). Knowledge in an uncertain world. Oxford: Oxford University Press.

Feldman, R. (2001). Voluntary belief and epistemic evaluation. In M. Steup (Ed.), Knowledge, truth, and duty: Essays on epistemic justification, responsibility, and virtue (pp. 77-92). Oxford: Oxford University Press.

Feldman, R. (2007). Reasonable religious disagreement. In L. Antony (Ed.), Philosophers without gods (pp. 197-214). Oxford: Oxford University Press.

Foley, R. (1992). The epistemology of belief and the epistemology of degrees of belief. American Philosophical Quarterly, 29, 2.

Foley, R. (1993). Epistemology of belief and the epistemology of degrees of belief. In Working without a net. Oxford: Oxford University Press (Chap. 4).

Foley, R. (2009). Introduction. In F. Huber \& C. Schmidt-Petri (Eds.), Degrees of belief: An anthology (pp. 1-33). Oxford: Oxford University Press.

Frankish, K. (2004). Mind and supermind. Cambridge: Cambridge University Press.

Frankish, K. (2009). Partial belief and flat-out belief. In F. Huber \& C. Schmidt-Petri (Eds.), Degrees of belief: An anthology. Oxford: Oxford University Press.

Friedman, J. (2013a). Rational agnosticism and degrees of belief. Oxford Studies in Epistemology, 45, 7.

Friedman, J. (2013b). Suspended judgment. Philosophical Studies, 162, 165-181. 
Ganson, D. (2008). Evidentialism and pragmatic constraints on outright belief. Philosophical Studies, 139, 3.

Ginet, C. (2001). Deciding to believe. In M. Steup (Ed.), Knowledge, truth, and duty: Essays on epistemic justification, responsibility, and virtue (pp. 63-76). Oxford: Oxford University Press.

Greco, D. (2015). How I learned to stop worrying and love probability 1. Philosophical Perspectives, 29, 179-201.

Greco, D., \& Hedden, B. (2016). Uniqueness and metaepistemology. Journal of Philosophy, 113(8), 365-395.

Hajek, A., \& Lin, H. (2017). A tale of two epistemologies? Res Philosophica, 94(2), 207-232.

Harman, G. (1986). Change in view. Cambridge, MA: MIT Press.

Harman, G. (2008). A change in view: Principles of reasoning. In Reasoning. Cambridge: Cambridge University Press.

Hawthorne, J. (2003). Knowledge and lotteries. Oxford: Oxford University Press.

Hawthorne, J. (2009). The Lockean thesis and the logic of belief. In F. Huber \& C. Schmidt-Petri (Eds.), Degrees of belief: An anthology (pp. 49-74). Oxford: Oxford University Press.

Hawthorne, J., \& Stanley, J. (2008). Knowledge and action. Journal of Philosophy, 105(10), 571-590.

Hedden, B. (2015). Reasons without persons: Rationality, identity, and time. Oxford: Oxford University Press.

Hieronymi, P. (2006). Controlling attitudes. Pacific Philosophical Quarterly, 87(1), 45-74.

Hieronymi, P. (2009). Believing at will. Canadian Journal of Philosophy, Supplementary, 35(1), 149-187.

Holton, R. (2008). Partial belief, partial intention. Mind, 117, 27-58.

Holton, R. (2014). Intention as a model for belief. In M. Vargas \& G. Yaffe (Eds.), Rational and social agency: Essays on the philosophy of Michael Bratman. Oxford: Oxford University Press.

Horgan, T. (2017). Troubles for Bayesian formal epistemology. Res Philosophica, 94(2), 233-255.

Hunter, D. (1996). On the relation between categorical and probabilistic belief. Nous, 30, 1.

Jackson, E. (MS). How belief-credence dualism explains away pragmatic encroachment.

Jackson, E., \& Moon, A. (MS). Credence: A belief-first approach.

Jeffrey, R. (1970). Dracula meets Wolfman: Acceptance vs. partial belief. In M. Swain (Ed.), Induction, acceptance, and rational belief (pp. 157-185). Dordrecht: Reidel.

Kahneman, D. (2013). Thinking fast and slow. New York: Farrar, Straus, and Giroux.

Kahneman, S., \& Tversky, A. (Eds.). (1982). Judgment under uncertainty: Heuristics and biases. Cambridge: Cambridge University Press.

Kaplan, M. (1996). Decision theory as philosophy. Cambridge: Cambridge University Press.

Kelly, T. (2005). The epistemic significance of disagreement. In Gendler, \& Hawthrone (Eds.), Oxford studies in epistemology (pp. 167-196) (Chap. 7).

Kelly, T. (2013). Evidence can be permissive. In M. Steup, J. Turri, \& E. Sosa (Eds.), Contemporary debates in epistemology (2nd ed., pp. 298-311). Hoboken: Wiley.

Kim, B. (2017). Pragmatic encroachment in epistemology. Philosophy Compass, 2, 1-14.

Konek, J. (forthcoming). Epistemic conservativity and imprecise credence. In Philosophy and phenomenological research.

Lance, M. N. (1995). Subjective probability and acceptance. Philosophical Studies, 77, 1.

Lee, M. (2017a). Credence and correctness: In defense of credal reductivism. Philosophical Papers, 46(2), 273-296.

Lee, M. (2017b). On the arbitrariness objection to the threshold view. Dialogue, 56, 143-158.

Leitgeb, H. (2013). Reducing belief simpliciter to degrees of belief. Annals of Pure and Applied Logic, 164, 1338-1389.

Leitgeb, H. (2014). The stability theory of belief. Philosophical Review, 123, 2.

Levi, I. (1991). The fixation of belief and its undoing: Changing beliefs through inquiry. Cambridge: Cambridge University Press.

Lewis, D. (1974). Radical interpretation. Synthese, 27, 331-344.

Lin, H. (2013). Foundations of everyday practical reasoning. Journal of Philosophical Logic, 42, $831-862$.

Littlejohn, C. (2015). Who cares about what you accurately believe? Philosophical Perspectives, 29, 217-248.

Locke, D. (2013). The decision theoretic lockean thesis. Inquiry, 57, 1.

Maher, P. (1993). Betting on theories. Cambridge: Cambridge University Press.

Meacham, C. (2014). Impermissive Bayesianism. Erkenntnis, 79, 1185-1217. 
Moon, A. (2017). Beliefs do not come in degrees. Canadian Journal of Philosophy, 47(6), 1-19.

Moon, A. (2018). The nature of doubt and a new puzzle about belief, doubt, and confidence. Synthese, 195(4), 1827-1848.

Moon, A. (forthcoming). A new puzzle about belief and credence. Canadian Journal of Philosophy.

Moss, S. (2013). Epistemology formalized. Philosophical Review, 122(1), 1-43.

Moss, S. (2018). Probabilistic knowledge. Oxford: Oxford University Press.

Moss, S. (forthcoming). Moral encroachment. In Proceedings of the aristotelian society.

Nagel, J. (2008). Knowledge ascriptions and the psychological consequences of changing stakes. Australiasian Journal of Philosophy, 86, 2.

Nagel, J. (2010a). Epistemic anxiety and adaptive invariantism. Philosophical Perspectives, 24, 407-435.

Nagel, J. (2010b). Knowledge ascriptions and the psychological consequences of thinking about error. The Philosophical Quarterly, 60, 239.

Pace, M. (2011). The epistemic value of moral considerations: Justification, moral encroachment, and James' 'will to believe'. Nous, 45, 2.

Pettigrew, R. (2015a). Accuracy and the credence-belief connection. Philosopher's Imprint, 15, 16.

Pettigrew, R. (2015b). Pluralism about belief states. Aristotelian Society Supplementary, 89, 1.

Pettigrew, R. (2016). Accuracy and the laws of Credence. Oxford: Oxford University Press.

Pittard, J. (MS). Credal voluntarism and Christian faith.

Plantinga, A. (1993). Warrant and proper function. Oxford: Oxford University Press.

Pollock, J. (1983). Epistemology and probability. Synthese, 55, 2.

Pollock, J. (1994). The role of probability in epistemology. Computational Intelligence, 10, 1.

Radcliffe, D. (1997). Scott-Kakures on believing at will. Philosophy and Phenomenological Research, 57(1), 145-151.

Roorda, J. (1995). Revenge of Wolfman: A probabilistic explication of full belief. Available at: https:// www.princeton.edu/ bayesway/pu/Wolfman.pdf.

Ross, J., \& Schroeder, M. (2014). Belief, credence, and pragmatic encroachment. Philosophy and Phenomenological Research, 88, 2.

Rothschild, D. (2012). Expressing credences. Proceedings of the Aristotelian Society, 112(1), 99-114.

Ryan, S. (2003). Doxastic compatibilism and the ethics of belief. Philosophical Studies, 114(1-2), 47-79.

Schoenfield, M. (2012). Chilling out on epistemic rationality. Philosophical Studies, 158, 197-219.

Schoenfield, M. (2014). Permission to believe: Why permissivism is true and what it tells us about irrelevant influences on belief. Noûs, 48, 193-218.

Schoenfield, M. (2015). The accuracy and rationality of imprecise credences. Noûs, 51, 667-685.

Schoenfield, M. (2018). Permissivism and the value of rationality: A challenge to the uniqueness thesis. In Philosophy and phenomenological research (online first).

Schroeder, M. (2012). Stakes, withholding, and pragmatic encroachment on knowledge. Philosophical Studies, 160(2), 265-285.

Scott-Kakures, D. (1994). On belief and the captivity of the will. Philosophy and Phenomenological Research, 54(1), 77-103.

Setiya, K. (2008). Believing at will. Midwest Studies in Philosophy, 32(1), 36-52.

Shah, N. (2002). Clearing space for doxastic voluntarism. The Monist, 85(3), 436-445.

Smith, M. (2010). A generalized lottery paradox for infinite probability spaces. British Journal for Philosophy of Science, 61, 821-831.

Sosa, E. (2011). Knowing full well. Princeton: Princeton University Press.

Staffel, J. (2017). Accuracy for believers. Episteme, Book Symposium on Pettigrew's Accuracy and the Laws of Credence, 14(1), 39-48.

Staffel, J. (2018). How do beliefs simplify reasoning? Nous. https://doi.org/10.1111/nous.12254.

Staffel, J. (forthcoming). Attitudes in active reasoning. In M. B. Jackson \& B. B. Jackson (Eds.), Reasoning: New essays on theoretical and practical thinking. Oxford: Oxford University Press.

Stalnaker, R. (1984). Inquiry. Cambridge, MA: MIT Press.

Stanley, J. (2005). Knowledge and practical interests. Oxford: Oxford University Press.

Steup, M. (2008). Doxastic freedom. Synthese, 161(3), 375-392.

Sturgeon, S. (2008). Reason and the grain of belief. Nous, 42(1), 139-165.

Sturgeon, S. (forthcoming). The rational mind. Oxford: Oxford University Press.

Tang, W. H. (2015). Belief and cognitive limitations. Philosophical Studies, 172, 1.

Weatherson, B. (2005). Can we do without pragmatic encroachment? Philosophical Perspectives, 19, 1.

Webster, D. M., \& Kruglanski, A. W. (1994). Individual differences in need for cognitive closure. Journal of Personality and Social Psychology, 67, 1049. 
Webster, D. M., \& Kruglanski, A. W. (1996). Motivated closing of the mind: Seizing and freezing. Psychological Review, 103(2), 263-289.

Wedgwood, R. (2012). Outright belief. Dialectica, 66, 3.

Weisberg, J. (2013). Knowledge in action. Philosopher's Imprint, 13, 22.

Weisberg, J. (forthcoming). Belief in psyontology. Philosopher's imprint. Available at: http:// jonathanweisberg.org/pdf/Psyontology.pdf.

White, R. (2005). Epistemic permissiveness. Philosophical Perspectives, 19, 445-459.

White, R. (2013). Evidence cannot be permissive. In M. Steup, J. Turri, \& E. Sosa (Eds.), Contemporary debates in epistemology (2nd ed., pp. 312-323). Hoboken: Wiley.

Williams, B. (1970). Deciding to believe. In B. Williams (Ed.), Problems of the self (pp. 136-151). Cambridge: Cambridge University Press.

Winters, B. (1979). Believing at will. Journal of Philosophy, 76(5), 243-256. 